\title{
EBV, HCMV, HHV6, and HHV7 Screening in Bone Marrow Samples from Children with Acute Lymphoblastic Leukemia
}

\author{
A. Morales-Sánchez, ${ }^{1,2,3}$ E. N. Pompa-Mera, ${ }^{4}$ A. Fajardo-Gutiérrez, ${ }^{1,5}$ \\ F. J. Alvarez-Rodríguez, ${ }^{5,6}$ V. C. Bekker-Méndez, ${ }^{4,5}$ J. de Diego Flores-Chapa, ${ }^{5,7}$ \\ J. Flores-Lujano, ${ }^{1,5}$ E. Jiménez-Hernández, ${ }^{5,8}$ J. G. Peñaloza-González, ${ }^{5,9}$ \\ M. C. Rodríguez-Zepeda, ${ }^{5,10}$ J. R. Torres-Nava, ${ }^{5,6}$ M. M. Velázquez-Aviña, ${ }^{5,9}$ \\ R. Amador-Sánchez, ${ }^{5,11}$ M. Alvarado-Ibarra, ${ }^{5,7}$ N. Reyes-Zepeda, ${ }^{5,7}$ \\ R. M. Espinosa-Elizondo, ${ }^{5,12}$ M. L. Pérez-Saldivar, ${ }^{1,5}$ J. C. Núñez-Enríquez, ${ }^{1,5}$ \\ J. M. Mejía-Aranguré, ${ }^{1,5}$ and E. M. Fuentes-Pananá ${ }^{2}$ \\ ${ }^{1}$ Unidad de Investigación Médica en Epidemiología Clínica, Hospital de Pediatría, CMN Siglo-XXI, \\ Instituto Mexicano del Seguro Social (IMSS), Avenida Cuauhtémoc 330, Colonia Doctores, 06720 México, DF, Mexico \\ ${ }^{2}$ Unidad de Investigación en Virología y Cáncer, Hospital Infantil de México Federico Gómez, Dr. Márquez 162, \\ Colonia Doctores, 06720 México, DF, Mexico \\ ${ }^{3}$ Facultad de Medicina, Universidad Nacional Autónoma de México, Avenida Universidad 3000, 04510 Mexico City, DF, Mexico \\ ${ }^{4}$ Unidad de Investigación Médica en Inmunología e Infectología, Hospital de Infectología, CMN La Raza, IMSS, \\ Calzada Vallejo y Jacarandas S/N Colonia La Raza, 02990 Mexico City, DF, Mexico \\ ${ }^{5}$ Grupo Mexicano Interinstitucional para la Identificación de las Causas de la Leucemia Infantil (GMIICLI), \\ Avenida Cuauhtémoc 330, Colonia Doctores, 06720 Mexico City, DF, Mexico \\ ${ }^{6}$ Servicio de Oncología, Hospital Pediátrico Moctezuma, Secretaría de Salud (SSa) del D.F., Oriente 158-189, \\ Colonia Moctezuma 2 a Sección, 15530 Mexico City, DF, Mexico \\ ${ }^{7}$ Servicio de Hematología Pediátrica, CMN 20 de Noviembre, Instituto de Seguridad Social al Servicio de los Trabajadores del Estado, \\ Félix Cuevas 540, Colonia Del Valle, 03229 Mexico City, DF, Mexico \\ ${ }^{8}$ Servicio de Hematología Pediátrica, Hospital General Gaudencio González Garza, CMN La Raza, IMSS, \\ Calzada Vallejo y Jacarandas S/N Colonia La Raza, 02990 Mexico City, DF, Mexico \\ ${ }^{9}$ Servicio de Onco-Pediatría, Hospital Juárez de México, SSa, Avenida Instituto Politécnico Nacional 5160, \\ Colonia Magdalena de las Salinas, 07760 Mexico City, DF, Mexico \\ ${ }^{10}$ Servicio de Hematología, UMAE, Hospital de Pediatría, CMN Siglo-XXI, IMSS, Avenida Cuauhtémoc 330, Colonia Doctores, \\ 06720 Mexico City, DF, Mexico \\ ${ }^{11}$ Hospital General Regional Carlos McGregor Sánchez Navarro, IMSS, Avenida Gabriel Mancera 222, Colonia Del Valle, \\ 03100 Mexico City, DF, Mexico \\ ${ }^{12}$ Servicio de Hematología Pediátrica, Hospital General de México, SSa, Eje 2 A Sur (Dr. Balmis) 148, Colonia Doctores, \\ 06726 Mexico City, DF, Mexico
}

Correspondence should be addressed to J. M. Mejía-Aranguré; juan.mejiaa@imss.gob.mx and E. M. Fuentes-Pananá; empanana@yahoo.com

Received 2 July 2014; Revised 26 August 2014; Accepted 26 August 2014; Published 18 September 2014

Academic Editor: Richard J. Q. McNally

Copyright (C) 2014 A. Morales-Sánchez et al. This is an open access article distributed under the Creative Commons Attribution License, which permits unrestricted use, distribution, and reproduction in any medium, provided the original work is properly cited.

Acute lymphoblastic leukemia (ALL) is the most common cancer in childhood worldwide and Mexico has reported one of the highest incidence rates. An infectious etiology has been suggested and supported by epidemiological evidences; however, the identity of the involved agent(s) is not known. We considered that early transmitted lymphotropic herpes viruses were good candidates, since transforming mechanisms have been described for them and some are already associated with human cancers. 
In this study we interrogated the direct role of EBV, HCMV, HHV6, and HHV7 human herpes viruses in childhood ALL. Viral genomes were screened in 70 bone marrow samples from ALL patients through standard and a more sensitive nested PCR. Positive samples were detected only by nested PCR indicating a low level of infection. Our result argues that viral genomes were not present in all leukemic cells, and, hence, infection most likely was not part of the initial genetic lesions leading to ALL. The high statistical power of the study suggested that these agents are not involved in the genesis of ALL in Mexican children. Additional analysis showed that detected infections or coinfections were not associated with prognosis.

\section{Introduction}

Acute lymphoblastic leukemia (ALL) is the most common childhood cancer worldwide and Mexico has reported one of the highest ALL incidence rates $[1,2]$. While new therapies have notably improved ALL outcome in recent years [3], pathogenic events leading to disease development remain largely unknown [4]. An infectious etiology has been suggested by different hypothesis favoring either direct or indirect mechanisms of transformation [5-7]. For infectious agents, direct oncogenic mechanisms refer to expression of viral oncogenes together with deregulation of cellular oncogenes and/or tumor suppressor genes. Indirect mechanisms are mainly triggered by an inflammatory milieu with production of mutagenic molecules or immunosuppression with loss of the cancer immune surveillance mechanisms [8]. The former mode of transformation implies that the infectious agent acts from within the cell and thus, after the cancer clonal expansion, it is carried in all tumor cells, as it has been documented for tumor herpes viruses $[9,10]$; while indirectly acting infectious carcinogenic agents do not necessarily infect the cell forming the tumor.

The Delayed infection hypothesis by Greaves proposes that exposure to infectious agents very early in life protects from ALL as it modulates maturation of the immune system. However, late exposures lead to an aberrant immune response promoting leukemogenesis by an indirect mechanism [5]. On the opposite side, Smith proposes that oncogenic viruses transmitted during intrauterine life or the first year of life are able to infect immature lymphocytes and promote leukemia through a direct transformation mechanism [7]. Epidemiological, clinical, and molecular evidence have been searched to support either direct or indirect mechanisms with variable and even opposite results (reviewed in [11]). We considered that the high incidence of childhood ALL in Mexico City was more closely correlated with high incidence of early infection of a developing country [1]. In agreement, we recently showed that serious infections requiring hospitalization in the first year of life were associated with increased risk of ALL in children with Down syndrome [12], better supporting the notion that early infections can promote pediatric leukemia as proposed by the Smith's hypothesis.

In this study, we explored the idea that viruses from which oncogenic capacities have been documented may promote leukemogenesis through a direct transforming mechanism. We selected members of the herpesviridae family, Epstein Barr virus (EBV), human cytomegalovirus (HCMV), and human herpes virus 6 (HHV6A and B) and 7 (HHV7) because they are lymphotropic viruses often transmitted in the first months of life. EBV is a potent transforming agent and has been consistently associated with several human malignancies including pediatric lymphomas [10]. Although, HCMV and HHV6 are not considered carcinogenic, their transforming ability has been shown in in vitro studies [1316]. Additionally, HCMV has been defined as oncomodulator because of its ability to infect tumor cells and alter proliferation, survival, angiogenesis, and invasiveness increasing the tumor aggressiveness $[17,18]$. HHV6 has previously been associated with several hematological malignances, including childhood acute leukemia, through serological case-control studies, although with heterogeneous results [19, 20]. An HHV7 transforming role has not been shown; however, there are proposals about its role as cofactor in T-cell and Bcell lymphomas $[21,22]$. Moreover, HHV7 may potentiate the pathogenic role of other herpes viruses [23, 24]. We assessed whether EBV, HCMV, HHV6, and HHV7 were involved in the genesis of childhood B-cell and T-cell ALL through a direct transformation mechanism. ALL bone marrow samples were tested by two PCRs with different detection limits. Considering that viruses acting through direct transforming mechanisms behave like driver genetic lesions that are preserved throughout tumor development, we designed a PCR test to equate the number of infected cells with the number of tumor cells and an even more sensitive PCR to detect evidence of infection. We found that less than $20 \%$ of the samples were positive by at least one of the viruses tested. Because positive samples showed low infection levels, these data do not support a direct role for EBV, HCMV, HHV6, and HHV7 in the genesis of pediatric ALL from Mexican children. Further analysis of the positives samples showed no association between detected infections or coinfections and prognosis.

\section{Materials and Methods}

2.1. Ethics Statement. This study was approved by the ethical and scientific review boards of the Mexican Institute of Social Security (IMSS): the National Commission of Scientific Research and the Ethics Committee on Research. Prior to sample collection, parents of enrolled patients were informed on the nature of the study and those who were willing to participate signed a letter of consent; children older than 10 years also signed a letter of assent. All patients enrolled were treated according to the ethical guidelines of our institution.

2.2. Patients and Biological Samples. The cases recruited in this study belong to the Mexican Inter-institutional Group for the Identification of the Causes of Childhood Leukaemia (MIGICCL; Mexico City, Mexico), a member of the Childhood Leukemia International Consortium (CLIC) since 2012. During the period of the study (January 1, 2010, to August 30, 
2012) there were 553 patients diagnosed with B- or T-cell ALL; however, there were sufficient bone marrow samples from only 70 pretreatment patients ( 66 from B-cell ALL and 4 from T-cell ALL) to include in the present study (Table 1). Two $\mathrm{mL}$ of bone marrow were collected in $0.1 \mathrm{M}$ sodium citrate solution (TEKNOVA, Hollister CA, USA) from the included patients and mononuclear cells were isolated by a density gradient centrifugation on Histopaque-1077 (Sigma-Aldrich, St. Luis, NO).

2.3. Control Cell Lines and Plasmid DNA. For EBV detection, Raji (ATCC, CCL-86) and Ramos (ATCC, CRL-1596) cell lines were used as positive and negative controls, respectively. Both cell lines were cultured in advanced RPMI medium supplemented with $4 \%$ of fetal bovine serum and $1 \mathrm{X}$ hepes (all from Gibco, Carlsbad, CA) and maintained at $37^{\circ} \mathrm{C}$ in $5 \%$ of $\mathrm{CO}_{2}$. Control plasmids were constructed for HCMV, HHV6, and HHV7 detection. Purified HCMV viral genome was kindly provided by Dr. M. Ruiz-Tachiquin (Pediatric Hospital at the CMN SXXI, IMSS, Mexico City, Mexico). HHV6 DNA was obtained from MOLT3 cell line (ATCC CRL-1552) infected with viral particles of HHV6 Z29 strain (ATCC VR1467). HHV7 DNA was purified from infected lymphocytes kindly provided by Dr. E. Sevilla (National Institute of Respiratory Diseases, Mexico City, Mexico). A fragment of HCMV UL83, HHV6 U94, and HHV7 U42 genes were PCR amplified using primers described in Table 2 (standard PCR) and cloned into T-easy pGEM plasmid (Promega, Madison, WI) according to manufacturer's instructions. The identity of cloned products was confirmed by sequencing.

2.4. DNA Purification. DNA was purified from bone marrow mononuclear cells or control cell lines using QIAamp DNA extraction kits (Qiagen, Hilden, Germany) according to the manufacturer's instructions. Plasmid DNA was purified using PureLink Quick Plasmid Miniprep Kit (Invitrogen, Carlsbad, CA) following the manufacturer's instruction. Purified DNA was quantified using a spectrophotometer NanoDrop 1000 (Thermo Fisher Scientific, Waltham, MA). The DNA quality and integrity were evaluated through electrophoretic landslide, optical density (260/280 ratio), and amplification of $\beta$ actin endogenous gene (genomic DNA).

2.5. Standard and Nested PCRs. Standard and nested PCR mix contained $1 \mathrm{x}$ Taq Polymerase buffer, 1.5 to $2.5 \mathrm{mM}$ $\mathrm{MgCl}_{2}\left(\mathrm{MgCl}_{2}\right.$ concentration was optimized for every PCR), $200 \mu \mathrm{M}$ deoxynucleotide triphosphate (dNTP), $2.5 \mathrm{U}$ of Taq Polymerase (all from Thermo Fisher Scientific, Waltham, MA), and $200 \mathrm{nM}$ of each primer (IDT Technologies). For standard PCR, $100 \mathrm{ng}$ of DNA from samples or control cell lines or $5.5 \times 10^{-5} \mathrm{ng}$ from control plasmid (equivalent to the number of moles contained in $100 \mathrm{ng}$ of genomic DNA) were used. Plasmids were linearized with restriction enzyme NdeI (New England BioLabs) before use and mixed with DNA from Daudi cell line in order to run the amplification reaction under identical mass/volume DNA concentration for both samples and controls. For the nested PCR, 0.5 or $0.05 \mu \mathrm{L}$ (1:100 or $1: 1000$ dilution resp.) of product of first round
TABLE 1: Demographic and clinic characteristics of the patients $N=$ 70.

\begin{tabular}{lc}
\hline Age at diagnosis (years) & $\begin{array}{c}\text { Median (range) } \\
7.6(0.8-15.7)\end{array}$ \\
\hline Gender & $N(\%)$ \\
Male & $33(47)$ \\
Female & $37(53)$ \\
\hline Birthplace & $N(\%)$ \\
Mexico City & $63(91)$ \\
Other Southern Mexican States & $7(9)$ \\
\hline Percentage of blasts in bone marrow & Average (range) \\
\hline Immunophenotype & $87 \%(25 \%-100 \%)$ \\
B-cell precursor & $N(\%)$ \\
T-cell & $66(94.3)$ \\
\hline FAB classification & $4(5.7)$ \\
L1 & $N(\%)$ \\
L2 & $43(62)$ \\
L3 & $26(36)$ \\
Genetic rearrangements ${ }^{* *}$ & $1(2)$ \\
ETV6-RUNX1 & $N(\%)$ \\
E2A-PBX1 & $6(12)$ \\
No rearrangement & $2(4)$ \\
\hline
\end{tabular}

${ }^{*}$ Immunophenotype was determined according to international parameters [54].

${ }^{* *}$ Molecular diagnosis of ETV6-RUNX1, E2A-PBX1, MLL-AF4 and major and minor BCR-ABL genetic rearrangements were performed only in 50 samples. Percentages shown were calculated using 50 as denominator.

PCR was used as template. All PCR reactions were carried out in a final volume of $50 \mu \mathrm{L}$. All primer sequences and cycling conditions used are detailed in Table 2. PCR products were analyzed by electrophoresis in $1.8 \%$ agarose gels stained with ethidium bromide and photographed under ultraviolet light using the Quantum ST4 System (VilberLourmat, Torcy, Marne-la-Vallée, FR). The viral identity of PCR amplified fragments was confirmed by sequencing.

2.6. Nucleotide Sequencing. The cloned viral gene fragments and PCR amplified fragments were excised from $1 \%$ agarose gels and purified using QIAquick gel extraction kit (Qiagen Hilden, Germany), following the manufacturer's instructions. Direct automated sequencing of both forward and reverse strands was carried out using the BigDye Terminator Cycle Sequencing kit (Applied Biosystems, Foster City, CA). About $20 \mathrm{ng}$ of template DNA was added for each reaction; the program included 25 cycles as described: denaturation at $95^{\circ} \mathrm{C}$ for $30 \mathrm{sec}$, annealing at $50^{\circ} \mathrm{C}$ for $15 \mathrm{sec}$, and extension at $60^{\circ} \mathrm{C}$ for $4 \mathrm{~min}$. Samples were analyzed in an ABI Prism 3130 Genetic Analyzer (Applied Biosystems, Foster City, CA). The obtained sequences were examined using the Nucleotide BLAST program [25].

2.7. Statistical Analysis. The statistical power of the study was calculated considering the sample size $(N=70)$ 
TABLE 2: PCR cycling conditions and primers sequences.

\begin{tabular}{|c|c|c|c|}
\hline Virus/endogenous gene & Type of PCR & Cycling conditions $^{(\mathrm{a})}$ & Primers sequences $\left(5^{\prime} \rightarrow 3^{\prime}\right)$ \\
\hline EBV & Standard & $95^{\circ} \mathrm{C} / 40 \mathrm{sec}, 57^{\circ} \mathrm{C} / 1 \mathrm{~min}, 72^{\circ} \mathrm{C} / 1.5 \min (30 X)$ & $\begin{array}{l}\text { F CCATGTAAGCTTGCCTCGAG } \\
\text { R GCCTTAGATCTGGCTCTTTG [55] }]^{(\mathrm{c})}\end{array}$ \\
\hline EBV & Nested & $95^{\circ} \mathrm{C} / 20 \mathrm{sec}, 57^{\circ} \mathrm{C} / 30 \mathrm{sec}, 72^{\circ} \mathrm{C} / 45 \mathrm{sec}(15 X)$ & $\begin{array}{l}\text { F CTTTGTCCAGATGTCAGGGG } \\
\text { R GCCTGAGCCTCTACTTTTGG }^{(\mathrm{b})}\end{array}$ \\
\hline CMV & Standard & $95^{\circ} \mathrm{C} / 1 \mathrm{~min}, 55^{\circ} \mathrm{C} / 1 \mathrm{~min}, 72^{\circ} \mathrm{C} / 1 \min (35 X)$ & $\begin{array}{l}\text { F AAGATGCGGTAGATGTCGTT } \\
\text { R CTGCGCTCTTCTTTTTCGAT }^{(\mathrm{b})}\end{array}$ \\
\hline CMV & Nested & $95^{\circ} \mathrm{C} / 45 \mathrm{sec}, 55^{\circ} \mathrm{C} / 45 \mathrm{sec}, 72^{\circ} \mathrm{C} / 45 \sec (15 X)$ & $\begin{array}{l}\text { F TTCTGACCCTGAACCGTAG } \\
\text { R CGACGAAGAACTCGTAACC }^{(b)}\end{array}$ \\
\hline $\mathrm{HHV}^{(\mathrm{d})}$ & Standard & $95^{\circ} \mathrm{C} / 1 \mathrm{~min}, 50^{\circ} \mathrm{C} / 1 \mathrm{~min}, 72^{\circ} \mathrm{C} / 1 \min (30 X)$ & $\begin{array}{l}\text { F GTGCGCTATAAAATCGATAGC } \\
\text { R TGATTTCCGTTGTGTGTTTTCC }^{(b)}\end{array}$ \\
\hline $\mathrm{HHV}^{(\mathrm{d})}$ & Nested & $95^{\circ} \mathrm{C} / 30 \mathrm{sec}, 56^{\circ} \mathrm{C} / 30 \mathrm{sec}, 72^{\circ} \mathrm{C} / 30 \mathrm{sec}(15 X)$ & $\begin{array}{l}\text { F GTCTCTTCGTATCCACGCG } \\
\text { R CGTTCCCGTCGAAGAAATC }^{(\mathrm{b})} \\
\end{array}$ \\
\hline HHV7 & Standard & $95^{\circ} \mathrm{C} / 45 \mathrm{sec}, 53^{\circ} \mathrm{C} / 45 \mathrm{sec}, 72^{\circ} \mathrm{C} / 45 \mathrm{sec}(30 \mathrm{X})$ & $\begin{array}{l}\text { F TTTTTACATTTGGCTTGCTTTTTG } \\
\text { R ATATTTCTGTACCTATCTTCCCAA [56 }]^{(\mathrm{c})}\end{array}$ \\
\hline HHV7 & Nested & $95^{\circ} \mathrm{C} / 30 \mathrm{sec}, 55^{\circ} \mathrm{C} / 30 \mathrm{sec}, 72^{\circ} \mathrm{C} / 30 \mathrm{sec}(15 X)$ & $\begin{array}{l}\text { F GAACGGTTTGCTTAGATTGC } \\
\text { R GCAGACCAAACTCCACAAATTC }^{(b)}\end{array}$ \\
\hline$\beta$-actin & Standard & $95^{\circ} \mathrm{C} / 1 \mathrm{~min}, 60^{\circ} \mathrm{C} / 1 \mathrm{~min}, 72^{\circ} \mathrm{C} / 1.5 \min (30 X)$ & $\begin{array}{l}\text { F CCTAAGGCCAACCGTGAAAAG } \\
\text { R TCTTCATGGTGCTAGGAGCCA [57] } \\
\text { (c) }\end{array}$ \\
\hline
\end{tabular}

and the probability to detect viral genomes supporting a direct transformation mechanism in at least one patient. The hypothetical frequencies of infection were $10 \%$ and $5 \%$. The statistical package used for this analysis was Epi Info version 7.1.4 (Centers for Disease Control and Prevention, http://wwwn.cdc.gov/epiinfo/). Odds ratios with 95\% confidence intervals were calculated to identify if the detected infections were associated with high-risk leukemia, relapse, or death. Mann-Whitney $U$ test was used to compare age in months and leukocyte count with infection. The statistical package used for these analyses was Epidat version 3.0.

\section{Results}

3.1. Study Population. The study included 70 pretreatment children diagnosed with ALL, 66 were B-cell ALL and 4 were T-cell ALL. The diagnosis of ALL fulfilled the morphological and phenotypic criteria, including that at least $25 \%$ of the cells from the bone marrow sample were leukemic blasts. Demographic and clinic characteristics of the patients were extracted from medical records and are presented in Table 1.

3.2. PCRs Limit of Detection. To know the limit of detection of the standard PCRs, we first carried out amplification reactions using serial dilutions of DNA from control cell lines and plasmids (Figure 1). For EBV detection, we employed Raji cell line, which derives from an EBV-associated lymphoma and carries about 50 viral episomes per cell [26]. The amplification target was the BamHI W fragment, which is eleven times repeated in the EBV genome. The lower limit of detection of our reaction was of $7.5 \times 10^{3}$ viral genomes
(Figure 1(a)). We decided to use $9.5 \times 10^{3}$ cells from bone marrow samples for EBV detection because we speculated that ALL samples might have similar frequencies to EBV episomes than those found in EBV-associated lymphomas. Still, if the number of viral genomes in leukemic cells were as low as the minimum reported for an EBV-associated cancer, namely, 7 viral genomes per cell in EBV-associated nasopharyngeal carcinoma [27], our test would be able to detect positive samples in as low as $25 \%$ of blasts (Figure 1(a)). For HCMV, HHV6, and HHV7 detection, we used plasmid DNA as control (see Material and Methods section). The limit of detection was about $0.97 \times 10^{3}$ plasmid copies for every reaction (Figures $1(\mathrm{~b}), 1(\mathrm{c})$, and $1(\mathrm{~d})$ ). As we did not know the number of HCMV, HHV6, and HHV7 genomes that could be present in each leukemic blast, DNA from control plasmid and samples were used at equal molar concentration. We determined that using $15.5 \times 10^{3}$ cells from samples (and $15.5 \times 10^{3}$ plasmid copies mixed with DNA from $15.5 \times$ $10^{3}$ negative cells as control) would be sufficient to detect up to one viral genome per cell even in samples with only $25 \%$ of leukemic blasts (Figures 1(b), 1(c), and 1(d)). We have previously used these PCRs in which the frequency of infected cells matches the frequency of cancer cells to address direct viral oncogenesis [28-30].

3.3. Viral Screening. Once the limit of detection was established for every reaction, we screened the presence of viral genomes in the samples. We do not observe any positive sample for any herpes virus tested by the first round PCR (Figures 2(a), 3(a), 4(a), and 5(a)). EBV, HCMV, and HHV6 positive samples were only detected through nested PCR in 


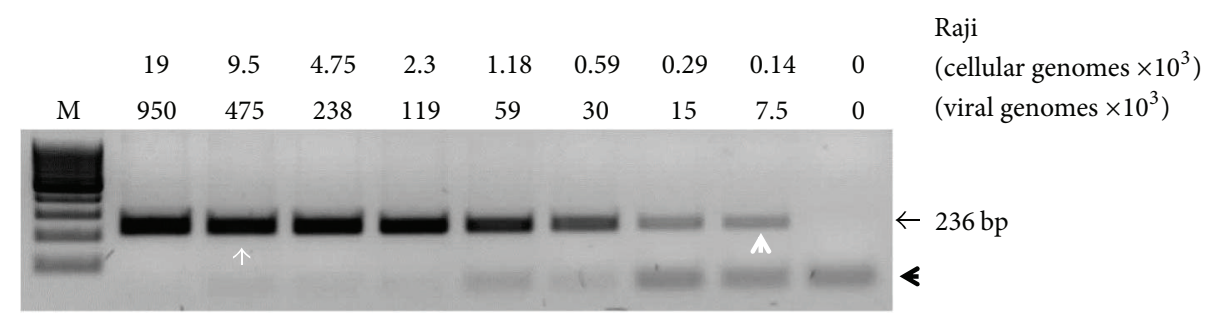

(a)

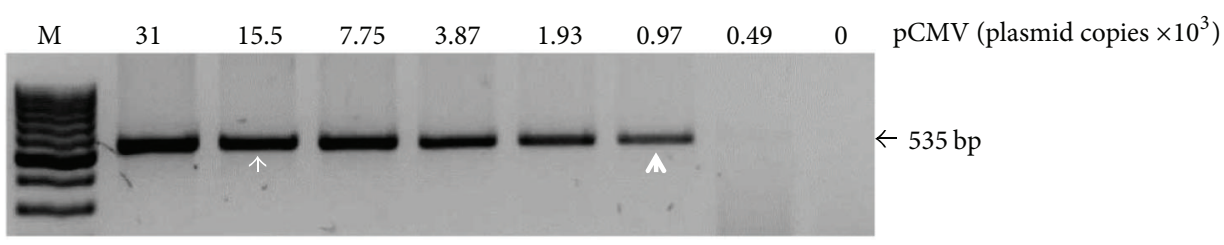

(b)

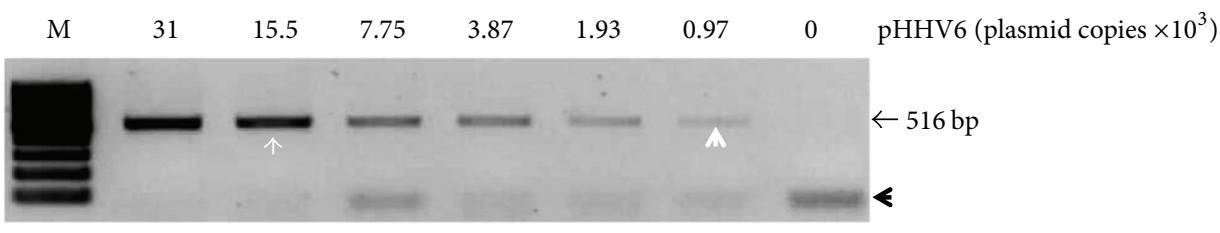

(c)

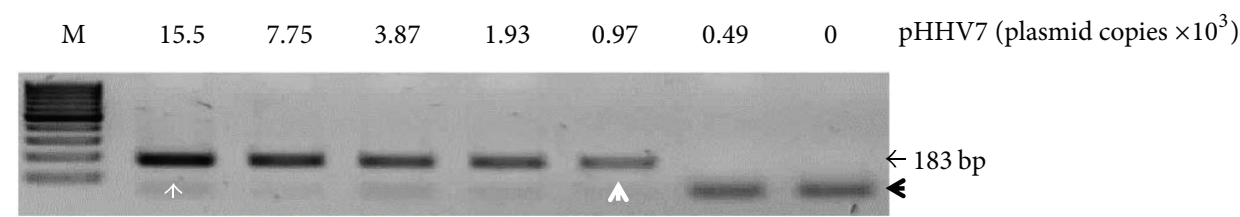

(d)

FIgURE 1: The PCRs limit of detection. Serial dilutions of DNA from control cell line and plasmid were PCR amplified in order to know the lower limit of detection of our screening test. For EBV (a), the limit of detection is expressed in number of cellular and viral genomes (from Raji cell line). For HCMV (b), HHV6 (c), and HHV7 (d) the limits of detection are expressed as plasmid copies. Lower limits of detection are indicated with a white arrowhead. White arrows point to the number of cells or plasmid copies that were used for viral detection in ALL samples. The sizes of PCR products are indicated. Black arrowheads point to residual primers.

the following frequencies: $14 \%, 19 \%$, and $9 \%$, respectively, while HHV7 was not detected by this method (Figures 2(b), 3(b), 4(b), and 5(b)). Considering that direct carcinogenic viruses contribute to oncogenesis acting like driver genetic lesions, we would consider that if viral infection had a role in the transformation of the cell subjected to oncogenic clonal expansion, the progeny of that cell should all carry the viral genome. In that scenario, the viral genome should have been detected by the first PCR in agreement with the previously established limit of detection. All samples showed high DNA integrity (not shown) and the amplification of $\beta$ actin endogenous gene was positive (Figures 2(c), 3(c), 4(c), and $5(\mathrm{c}))$.

3.4. Power of the Study. We carried out a post hoc power analysis to calculate the probability that our results were true based in the obtained sample size and the frequency of the infection. The frequency of the infection was hypothetical because up to today none of the viruses studied have been shown to cause ALL. The statistical power test indicated that the probability to detect at least one positive subject (in the first PCR, supporting a direct transforming) from our study population $(N=70)$ was $99.99 \%$ and $95.00 \%$ from hypothetical frequencies of infection of $10 \%$ and $5 \%$, respectively. Thus, our results suggest that EBV, HCMV, HHV6, and HHV7 are not involved in the genesis of childhood ALL in Mexican children.

3.5. Analysis of Infection and Prognosis. A possible role of the detected infections in prognosis was explored. Considering a previously documented probable interaction between the herpes viruses tested [31-35] we calculated the association between every infection or coinfection and the risk for high-risk leukemia, relapse, or death (Table 3). Coinfections included only double-infections: $\mathrm{EBV}+/ \mathrm{HCMV}+$, $\mathrm{EBV}+/ \mathrm{HHV} 6+$, and $\mathrm{HCMV}+/ \mathrm{HHV} 6+$; triple infections were not detected. We did not find any significant association with this analysis (Table 3 ). We also compared the age (in months) at the moment of diagnosis and the leukocyte count between infected and noninfected children finding 




(a)

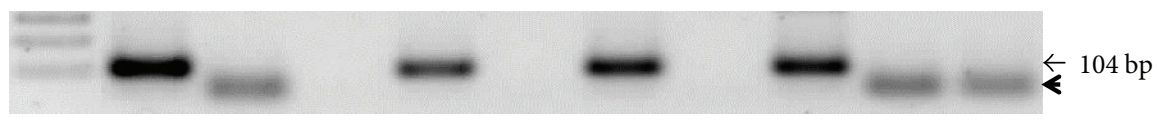

(b)



(c)

FIGURE 2: EBV screening. Image of seven representative samples showing that all of them were EBV negative by first round PCR (a) and positivity was only detected by nested PCR in 10 (14\%; showing three) samples (b). Raji and Ramos (Ram) cell lines were used as positive and negative controls, respectively. A reaction without DNA was routinely run (-). (c) Amplification of $\beta$-actin endogenous gene. The sizes of PCR products are indicated. The black arrowhead points to residual primers.

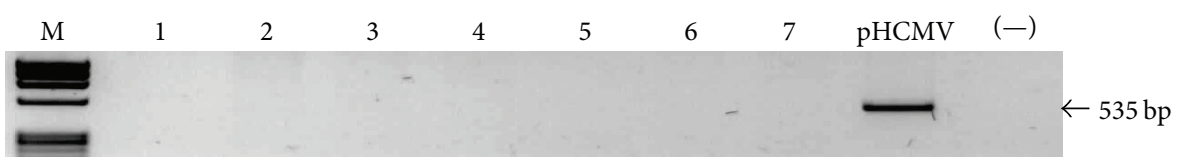

(a)

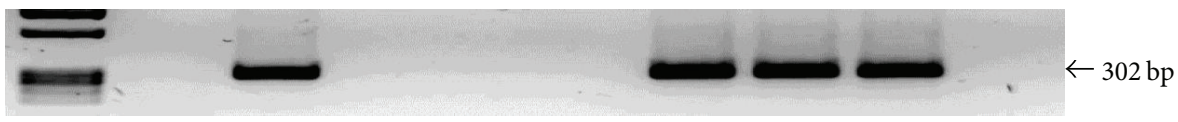

(b)



(c)

FIGURE 3: HCMV screening. Image of seven representative samples showing that all of them were HCMV negative by first round PCR (a) and positivity was only detected by nested PCR in 13 (19\%, showing three) samples (b). Plasmid DNA was used as positive control (pHCMV). A reaction without DNA was routinely run (-). (c) Amplification of $\beta$-actin endogenous gene. The sizes of PCR products are indicated.

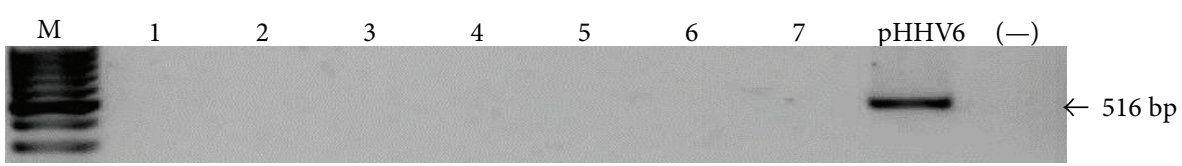

(a)

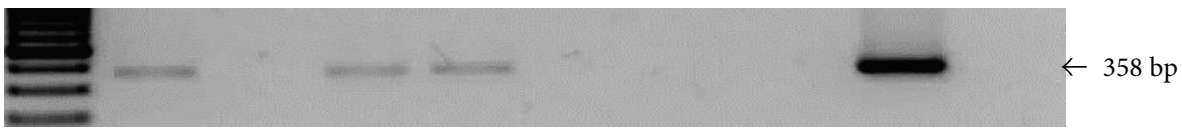

(b)

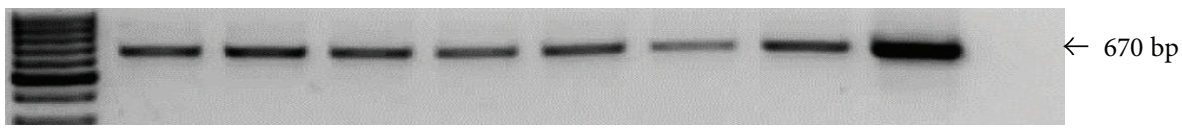

(c)

FIGURE 4: HHV6 screening. Image of seven representative samples showing that all of them were HHV6 negative by first round PCR (a) and positivity was only detected by nested PCR in 6 ( $9 \%$, showing three) samples (b). Plasmid DNA was used as positive control (pHHV6). A reaction without DNA was routinely run (-). (c) Amplification of $\beta$-actin endogenous gene. The sizes of PCR products are indicated. 


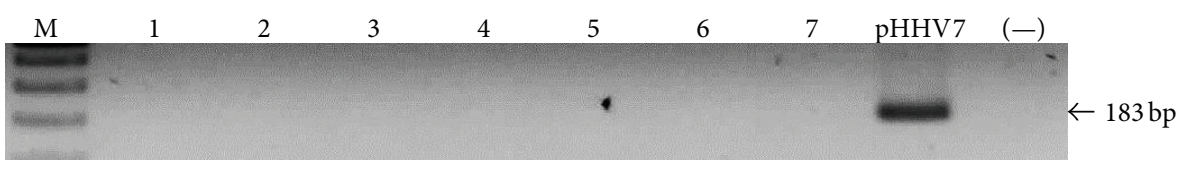

(a)

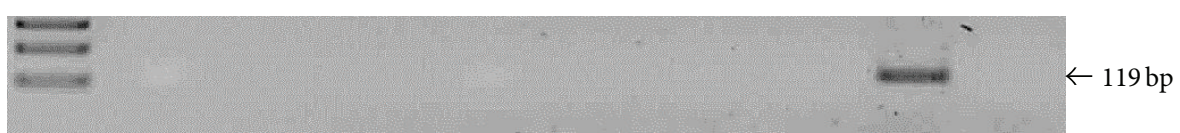

(b)

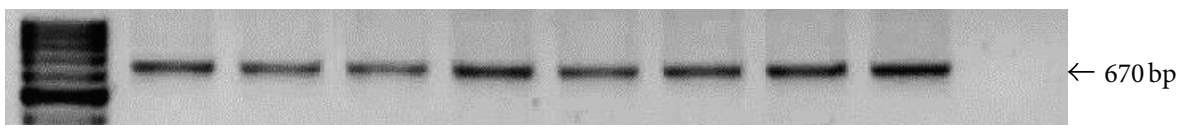

(c)

FIGURE 5: HHV7 screening. Image of seven representative samples showing that all of them were HHV7 negative by both first round PCR (a) and nested PCR (b). Plasmid DNA was used as positive control (pHHV7). A reaction without DNA was routinely run (-). (c) Amplification of $\beta$-actin endogenous gene. The sizes of PCR products are indicated.

TABLE 3: Infection and prognostic factors.

\begin{tabular}{|c|c|c|c|c|}
\hline $\begin{array}{l}\text { Virus } \\
N(\%)\end{array}$ & $\begin{array}{c}\text { EBV+ } \\
10(14 \%)\end{array}$ & $\begin{array}{c}\text { HCMV+ } \\
13(19 \%)\end{array}$ & $\begin{array}{c}\text { HHV6+ } \\
6(9 \%)\end{array}$ & $\begin{array}{c}\text { Any coinfection } \\
6(9 \%)\end{array}$ \\
\hline \multicolumn{5}{|c|}{ High-risk leukemia } \\
\hline OR (95\% IC) & $0.43(0.12-1.57)$ & $0.72(0.22-2.32)$ & $2.29(0.4-15.32)$ & $1.12(0.24-5.2)$ \\
\hline$P$ & 0.29 & 0.75 & 0.4 & 1 \\
\hline \multicolumn{5}{|l|}{ Relapse } \\
\hline OR (95\% IC) & $1.19(0.27-5.36)$ & $0.88(0.20-3.82)$ & $1.10(0.15-6.63)$ & $0.81(0.12-4.67)$ \\
\hline$P$ & 1 & 1 & 1 & 1 \\
\hline \multicolumn{5}{|l|}{ Death } \\
\hline OR (95\% IC) & $0.17(0.02-1.14)$ & $0.16(0.02-1.08)$ & $0.04(0.04-2.81)$ & $0.37(0.05-2.03)$ \\
\hline$P$ & 0.89 & 0.08 & 0.65 & 0.41 \\
\hline
\end{tabular}

OR: odds ratio; CI: confidence interval. $P<0.05$ was considered significant.

no significant differences (not shown). These results argued against a possible indirect role of these infections in the onset and the course of disease.

\section{Discussion}

Epidemiological data suggest the involvement of infections in the etiology of childhood ALL; however, the identity of the potentially implicated agent(s) has not been identified. Based on the original Smith's proposal about a direct causative role of viral agents in ALL development [7], we screened the presence of EBV, HCMV, HHV6, and HHV7 viral genomes in B-cell and T-cell ALL samples by a standard PCR aiming to match the number of infected cells with the number of leukemic blasts. The infectious etiology of childhood leukemia has been mainly proposed for common B-cell ALL $[5,7]$. However, in this work, the viral screening in T-cell ALL was performed as an exploratory analysis based in the known T-cell tropism of the studied herpes viruses. Also, EBV is the causative agent of T-cell lymphomas [36, 37] and a role of EBV in the etiology of T-cell leukemia has been suggested [38].
We found no evidence of the participation of EBV, HCMV, HHV6, and HHV7 in the B-cell and T-cell ALL development. Positive samples were detected only through a more sensitive nested PCR, most likely reflecting normal levels of infection according to the age of the tested population. Positivity only by nested PCR does not support a relationship between infection and leukemogenesis. Still, the nested PCR was implemented as an additional control to globally validate our detection system. Based on the knowledge that the herpes viruses under study are ubiquitously acquired early in life and maintain a reservoir population in bone marrow, we expected to obtain positive samples by a sensitive detection, reflecting the common infection occurring in the pediatric population.

Previous studies looked for the presence of DNA viruses in bone marrow or peripheral blood from childhood ALL samples, namely, JVC, BKV, and SV40 polyomaviruses [39, 40]; TT anellovirus [41] and EBV and HHV-6, -7, and -8 herpes viruses [42]. Nevertheless all of them have failed to find evidence of their participation in the disease. Although, there is a previous work analyzing the participation of herpes viruses in leukemogenesis with similar negative results, based on the epidemiological differences between our country and 
developed countries related to the increased prevalence of infections and childhood leukemias in Mexico [1], we hypothesized that a mechanism of direct leukemogenesis could explain some cases of leukemia in our population. An advantage of our work over previous studies is the number of samples analyzed, $N=70$ in our study versus $N=$ 15-47 in others; which conferred it a higher statistical power. Also, other works screened the presence of viral genomes of EBV and HHV6 herpes viruses [43], JVC and BKV polyomaviruses [44], and parvovirus B19 [45] in archived neonatal blood spots collected at birth from children who developed leukemia, however, these works lost the window of infections happening from birth to the presentation of the disease. Additionally, this is the first work reporting no association between HCMV and childhood ALL. We have also previously reported that human T-cell lymphotropic virus type 1 (HTLV1) and mouse mammary tumor virus like virus (MMTV-LV) were not involved in the genesis of childhood ALL [29].

Indirect mechanisms of leukemogenesis are also possible but addressing those mechanisms was beyond the aim of this study. Still, we did not find any evident association between nested PCR positive patients and clinical data. Previous studies have supported a role for EBV in genetic instability and EBV-associated Burkitt's lymphoma is characterized by a $M y c$ genetic translocation [46-48]. However, the low number of patients with genetic translocations in our study $(N=8)$ precluded an analysis of EBV infection and ALL-associated genetic translocations with significant statistical power. It is proposed that herpes viruses often act in concert potentiating their pathological effects in cases of chronic fatigue syndrome, infectious mononucleosis, and/or posttransplant disease [31-35]. Although, we had a sizable number of infection positive patients, most of them were single infected, with only 6 (9\%) showing evidence of infection by more than one herpes virus (see Table 3). Therefore, we do not have any evidence of a possible interaction by the tested viruses.

It is possible that the lymphoproliferation that characterizes ALL results from continuous immune stimulation triggered by repetitive infections. However, almost any infectious agent would be responsible for this effect and only tumor viruses with documented or possible direct transforming properties were tested here. There exist some examples of chronic antigenic stimulation leading to lymphomas, for instance, MALT lymphoma after Helicobacter pylori persistent infection and hepatitis $\mathrm{C}$ virus associated lymphoma [49-52]. Since those are adult neoplasias arising after decades of antigenic stimulation it is unlikely that pediatric ALL could result from a similar mechanism and arise as the immune system responds to a single infection. In any case, it is more likely that multiple antigenic challenges combined with maturing lymphocytes with a genetic lesion, for example, an intrauterine translocation, were involved in the genesis of ALL. In lymphomas of mature cells, the identity of the target of the antigen receptor (VDJ recombination clone) gives light to the origin of the lymphoproliferation. Since ALL occurs in progenitor cells in which more often the leukemic blasts have not completed the rearrangements of the antigen receptor, this is a scenario more difficult to corroborate.
An important limitation of all studies searching for infectious agents in pediatric ALL is that all have been performed individually, testing samples through standard techniques of molecular biology (PCR and/or Southern blot). Such strategies are restricted to agents whose genomic sequences have been at least partially described. Future investigations should use next-generation sequencing technologies and bioinformatic analysis that are more able to detect the full spectrum of viruses including those still not described, as it has been recently shown for Merkel cell polyomavirus [53]. Besides tumor viruses, indirect mechanisms of leukemogenesis also need to be addressed in order to better understand the role that a history of infection has in the development of pediatric ALL.

\section{Conflict of Interests}

The authors declare that there is no conflict of interests regarding the publication of this paper.

\section{Authors' Contribution}

J. M. Mejía-Aranguré and E. M. Fuentes-Pananá contributed equally to this work.

\section{Acknowledgments}

This work was funded by the National Council of Science and Technology (CONACyT), Grants 2010-1-141026, CB-2007-1-83949, and 2007-1-18-71223; by the Mexican Institute of Social Security (Mexico City, Mexico), Grant FIS/IMSS/PROT/G10/846 (to J. M. Mejía-Aranguré); and by Fondo de Apoyo a la Investigación HIMFG (to E. M. FuentesPananá). This work constitutes a partial fulfillment of the Graduate Program of Doctor Degree in Biomedical Sciences, Medicine Faculty, National Autonomous University of Mexico, Mexico City, Mexico. A. Morales-Sánchez acknowledges the scholarship and financial support provided by the National Council of Science and Technology (CONACyT), the National Autonomous University of Mexico, and the Mexican Institute of the Social Security (IMSS).

\section{References}

[1] M. L. Perez-Saldivar, A. Fajardo-Gutiérrez, R. Bernáldez-Ríos et al., "Childhood acute leukemias are frequent in Mexico City: descriptive epidemiology," BMC Cancer, vol. 11, p. 355, 2011.

[2] M. P. Curado, B. Edwards, H. R. Shin et al., Cancer Incidence in Five Continents IARC Scientific Publications, The International Agency for Research on Cancer (IARC), Lyon, France, 2007.

[3] C.-H. Pui, W. L. Carroll, S. Meshinchi, and R. J. Arceci, "Biology, risk stratification, and therapy of pediatric acute leukemias: an update," Journal of Clinical Oncology, vol. 29, no. 5, pp. 551-565, 2011.

[4] C. H. Pui, L. L. Robison, and A. T. Look, "Acute lymphoblastic leukaemia," The Lancet, vol. 371, no. 9617, pp. 1030-1043, 2008.

[5] M. Greaves, "Infection, immune responses and the aetiology of childhood leukaemia," Nature Reviews Cancer, vol. 6, no. 3, pp. 193-203, 2006. 
[6] L. Kinlen, "Childhood leukaemia, nuclear sites, and population mixing," British Journal of Cancer, vol. 104, no. 1, pp. 12-18, 2011.

[7] M. Smith, "Considerations on a possible viral etiology for Bprecursor acute lymphoblastic leukemia of childhood," Journal of Immunotherapy, vol. 20, no. 2, pp. 89-100, 1997.

[8] P. S. Moore and Y. Chang, "Why do viruses cause cancer? Highlights of the first century of human tumour virology," Nature Reviews Cancer, vol. 10, no. 12, pp. 878-889, 2010.

[9] K. W. Wen and B. Damania, "Kaposi sarcoma-associated herpesvirus (KSHV): molecular biology and oncogenesis," Cancer Letters, vol. 289, no. 2, pp. 140-150, 2010.

[10] L. S. Young and P. G. Murray, "Epstein-Barr virus and oncogenesis: from latent genes to tumours," Oncogene, vol. 22, no. 33, pp. 5108-5121, 2003.

[11] A. Morales-Sánchez and E. M. Fuentes-Panana, "Infectious etiology of childhood acute lymphoblastic leukemia, hypotheses and evidence," in Clinical Epidemiology of Acute Lymphoblastic Leukemia-From the Molecules to the Clinic, J. M. MejiaArangure, Ed., pp. 19-39, Intech, Rijeta, Croatia, 2013.

[12] J. Flores-Lujano, M. L. Perez-Saldivar, E. M. Fuentes-Pananá et al., "Breastfeeding and early infection in the aetiology of childhood leukaemia in down syndrome," British Journal of Cancer, vol. 101, no. 5, pp. 860-864, 2009.

[13] A. Razzaque, "Oncogenic potential of human herpesvirus-6 DNA," Oncogene, vol. 5, no. 9, pp. 1365-1370, 1990.

[14] A. Razzaque, O. Williams, J. Wang, and J. S. Rhim, "Neoplastic transformation of immortalized human epidermal keratinocytes by two HHV-6 DNA clones," Virology, vol. 195, no. 1, pp. 113-120, 1993.

[15] K. M. Geder, R. Lausch, F. O’Neill, and F. Rapp, “Oncogenic transformation of human embryo lung cells by human cytomegalovirus," Science, vol. 192, no. 4244, pp. 1134-1137, 1976.

[16] L. Geder, J. Kreider, and F. Rapp, "Human cells transformed in vitro by human cytomegalovirus: tumorigenicity in athymic nide mice," Journal of the National Cancer Institute, vol. 58, no. 4, pp. 1003-1009, 1977.

[17] K. Barami, "Oncomodulatory mechanisms of human cytomegalovirus in gliomas," Journal of Clinical Neuroscience, vol. 17, no. 7, pp. 819-823, 2010.

[18] J. Cinatl Jr., J.-U. Vogel, R. Kotchetkov, and H. W. Doerr, "Oncomodulatory signals by regulatory proteins encoded by human cytomegalovirus: a novel role for viral infection in tumor progression," FEMS Microbiology Reviews, vol. 28, no. 1, pp. 59-77, 2004.

[19] M. J. H. Salonen, M. A. Siimes, E.-M. Salonen, A. Vaheri, and M. Koskiniemi, "Antibody status to HHV-6 in children with leukaemia," Leukemia, vol. 16, no. 4, pp. 716-719, 2002.

[20] P. H. Levine, D. V. Ablashi, W. C. Saxinger, and R. R. Connelly, "Antibodies to human herpes virus- 6 in patients with acute lymphocytic leukemia," Leukemia, vol. 6, no. 11, pp. 1229-1231, 1992.

[21] E. Nagore, E. Ledesma, C. Collado, V. Oliver, A. Pérez-Pérez, and A. Aliaga, "Detection of Epstein-Barr virus and human herpesvirus 7 and 8 genomes in primary cutaneous T- and Bcell lymphomas," British Journal of Dermatology, vol. 143, no. 2, pp. 320-323, 2000.

[22] R. Ponti, M. Bergallo, C. Costa et al., "Human herpesvirus 7 detection by quantitative real time polymerase chain reaction in primary cutaneous T-cell lymphomas and healthy subjects: Lack of a pathogenic role," British Journal of Dermatology, vol. 159, no. 5, pp. 1131-1137, 2008.
[23] S. Chapenko, I. Folkmane, V. Tomsone, D. Amerika, R. Rozentals, and M. Murovska, "Co-infection of two $\beta$-herpesviruses (CMV and HHV-7) as an increased risk factor for "CMV disease" in patients undergoing renal transplantation," Clinical Transplantation, vol. 14, no. 5, pp. 486-492, 2000.

[24] H. K. Osman, J. S. Peiris, C. E. Taylor, P. Warwicker, R. F. Jarrett, and C. R. Madeley, “'Cytomegalovirus disease' in renal allograft recipients: is human herpesvirus 7 a co-factor for disease progression?" Journal of Medical Virology, vol. 48, no. 4, pp. 295-301, 1996.

[25] S. F. Altschul, W. Gish, W. Miller, E. W. Myers, and D. J. Lipman, "Basic local alignment search tool," Journal of Molecular Biology, vol. 215, no. 3, pp. 403-410, 1990.

[26] A. Adams, "Replication of latent Epstein-Barr virus genomes in Raji cells," Journal of Virology, vol. 61, no. 5, pp. 1743-1746, 1987.

[27] P. Liu, X. Fang, Z. Feng et al., "Direct sequencing and characterization of a clinical isolate of epstein-barr virus from nasopharyngeal carcinoma tissue by using next-generation sequencing technology," Journal of Virology, vol. 85, no. 21, pp. 11291-11299, 2011.

[28] J. L. Martinez-Lopez, J. Torres, M. Camorlinga-Ponce et al., "Evidence of Epstein-Barr virus association with gastric cancer and non-atrophic gastritis," Viruses, vol. 6, no. 1, pp. 301-318, 2014.

[29] A. Morales-Sanchez, R. Bernáldez-Ríos, F. J. Alvarez-Rodríguez et al., "Lack of evidence for human T-lymphotropic virus type 1 and mouse mammary tumor-like virus involvement in the genesis of childhood acute lymphoblastic leukemia," Cancer Epidemiology, Biomarkers \& Prevention, vol. 22, no. 11, pp. 21302133, 2013.

[30] A. Morales-Sanchez, T. Molina-Muñoz, J. L. Martínez-López et al., "No association between Epstein-Barr virus and Mouse Mammary tumor virus with breast cancer in Mexican women," Scientific Reports, vol. 3, p. 2970, 2013.

[31] S. Chapenko, A. Krumina, I. Logina et al., "Association of active human herpesvirus-6, -7 and parvovirus B19 infection with clinical outcomes in patients with myalgic encephalomyelitis/chronic fatigue syndrome," Advances in Virology, vol. 2012, Article ID 205085, 7 pages, 2012.

[32] X. Wang, K. Yang, C. Wei, Y. Huang, and D. Zhao, "Coinfection with EBV/CMV and other respiratory agents in children with suspected infectious mononucleosis," Virology Journal, vol. 7, article 247, 2010.

[33] "Other herpesviruses: HHV-6, HHV-7, HHV-8, HSV-1 and -2, VZV," American Journal of Transplantation, vol. 4, supplement 10, pp. 66-71, 2004.

[34] I. M. Kidd, D. A. Clark, C. A. Sabin et al., "Prospective study of human betaherpesviruses after renal transplantation: association of human herpesvirus 7 and cytomegalovirus coinfection with cytomegalovirus disease and increased rejection," Transplantation, vol. 69, no. 11, pp. 2400-2404, 2000.

[35] V. M. Ratnamohan, J. Chapman, H. Howse et al., "Cytomegalovirus and human herpesvirus 6 both cause viral disease after renal transplantation," Transplantation, vol. 66, no. 7, pp. 877-882, 1998.

[36] H. Kimura, Y. Ito, S. Kawabe et al., "EBV-associated T/NKcell lymphoproliferative diseases in nonimmunocompromised hosts: prospective analysis of 108 cases," Blood, vol. 119, no. 3, pp. 673-686, 2012.

[37] A. Carbone, A. Gloghini, and G. Dotti, "EBV-associated lymphoproliferative disorders: classification and treatment," Oncologist, vol. 13, no. 5, pp. 577-585, 2008. 
[38] S. Sakajiri, K. Mori, Y. Isobe, N. Kawamata, and K. Oshimi, "Epstein-Barr virus-associated T-cell acute lymphoblastic leukaemia," The British Journal of Haematology, vol. 117, no. 1, pp. 127-129, 2002.

[39] J. MacKenzie, J. Perry, A. M. Ford, R. F. Jarrett, and M. Greaves, "JC and BK virus sequences are not detectable in leukaemic samples from children with common acute lymphoblastic leukaemia," British Journal of Cancer, vol. 81, no. 5, pp. 898-899, 1999.

[40] M. A. Smith, "Investigation of leukemia cells from children with common acute lymphoblastic leukemia for genomic sequences of the primate polyomaviruses JC virus, $\mathrm{BK}$ virus, and simian virus 40," Medical and Pediatric Oncology, vol. 33, no. 5, pp. 441443, 1999.

[41] B. Shiramizu, Q. Yu, N. Hu, R. Yanagihara, and V. R. Nerurkar, "Investigation of TT virus in the etiology of pediatric acute lymphoblastic leukemia," Pediatric Hematology \& Oncology, vol. 19, no. 8, pp. 543-551, 2002.

[42] J. Mackenzie, A. Gallagher, R. A. Clayton et al., "Screening for herpesvirus genomes in common acute lymphoblastic leukemia," Leukemia, vol. 15, no. 3, pp. 415-421, 2001.

[43] G. Bogdanovic, G. Jernberg, P. Priftakis, L. Grillner, and B. Gustafsson, "Human herpes virus 6 or Epstein-Barr virus were not detected in Guthrie cards from children who later developed leukaemia," British Journal of Cancer, vol. 91, no. 5, pp. 913-915, 2004.

[44] P. Priftakis, T. Dalianis, J. Carstensen et al., "Human polyomavirus DNA is not detected in Guthrie cards (dried blood spots) from children who developed acute lymphoblastic leukemia," Medical and Pediatric Oncology, vol. 40, no. 4, pp. 219-223, 2003.

[45] A. Isa, P. Priftakis, K. Broliden, and B. Gustafsson, "Human parvovirus B19 DNA is not detected in Guthrie cards from children who have developed acute lymphoblastic leukemia," Pediatric Blood and Cancer, vol. 42, no. 4, pp. 357-360, 2004.

[46] J. H. Kim, W. S. Kim, and C. Park, "Epstein-Barr virus latent membrane protein 1 increases genomic instability through Egr-1-mediated up-regulation of activation-induced cytidine deaminase in B-cell lymphoma," Leukemia and Lymphoma, vol. 54, no. 9, pp. 2035-2040, 2013.

[47] S. A. Kamranvar, B. Gruhne, A. Szeles, and M. G. Masucci, "Epstein-Barr virus promotes genomic instability in Burkitt's lymphoma," Oncogene, vol. 26, no. 35, pp. 5115-5123, 2007.

[48] G. W. Bornkamm, "Epstein-Barr virus and the pathogenesis of Burkitt's lymphoma: more questions than answers," International Journal of Cancer, vol. 124, no. 8, pp. 1745-1755, 2009.

[49] P. G. Isaacson and M.-Q. Du, "MALT lymphoma: from morphology to molecules," Nature Reviews Cancer, vol. 4, no. 8, pp. 644-653, 2004.

[50] D. Rosa, G. Saletti, E. De Gregorio et al., "Activation of naïve B lymphocytes via CD81, a pathogenetic mechanism for hepatitis $\mathrm{C}$ virus-associated B lymphocyte disorders," Proceedings of the National Academy of Sciences of the United States of America, vol. 102, no. 51, pp. 18544-18549, 2005.

[51] X. Sagaert, E. van Cutsem, G. de Hertogh, K. Geboes, and T. Tousseyn, "Gastric MALT lymphoma: a model of chronic inflammation-induced tumor development," Nature Reviews Gastroenterology and Hepatology, vol. 7, no. 6, pp. 336-346, 2010.

[52] D. S. Viswanatha and A. Dogan, "Hepatitis C virus and lymphoma," Journal of Clinical Pathology, vol. 60, no. 12, pp. 1378-1383, 2007.
[53] H. Feng, M. Shuda, Y. Chang, and P. S. Moore, "Clonal integration of a polyomavirus in human Merkel cell carcinoma," Science, vol. 319, no. 5866, pp. 1096-1100, 2008.

[54] R. Bernaldez-Rios, M. C. Ortega-Alvarez, M. L. Perez-Saldivar et al., "The age incidence of childhood B-cell precursor acute lymphoblastic leukemia in Mexico City," Journal of Pediatric Hematology/Oncology, vol. 30, no. 3, pp. 199-203, 2008.

[55] L. G. Labrecque, D. M. Barnes, I. S. Fentiman, and B. E. Griffin, "Epstein-Barr virus in epithelial cell tumors: a breast cancer study," Cancer Research, vol. 55, no. 1, pp. 39-45, 1995.

[56] I. M. Kidd, D. A. Clark, M. Ait-Khaled, P. D. Griffiths, and V. C. Emery, "Measurement of human herpesvirus 7 load in peripheral blood and saliva of healthy subjects by quantitative polymerase chain reaction," Journal of Infectious Diseases, vol. 174, no. 2, pp. 396-401, 1996.

[57] E. M. Fuentes-Pananá, G. Bannish, N. Shah, and J. G. Monroe, "Basal Igalpha/Igbeta signals trigger the coordinated initiation of pre-B cell antigen receptor-dependent processes," Journal of Immunology, vol. 173, no. 2, pp. 1000-1011, 2004. 


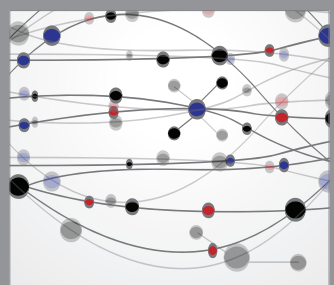

The Scientific World Journal
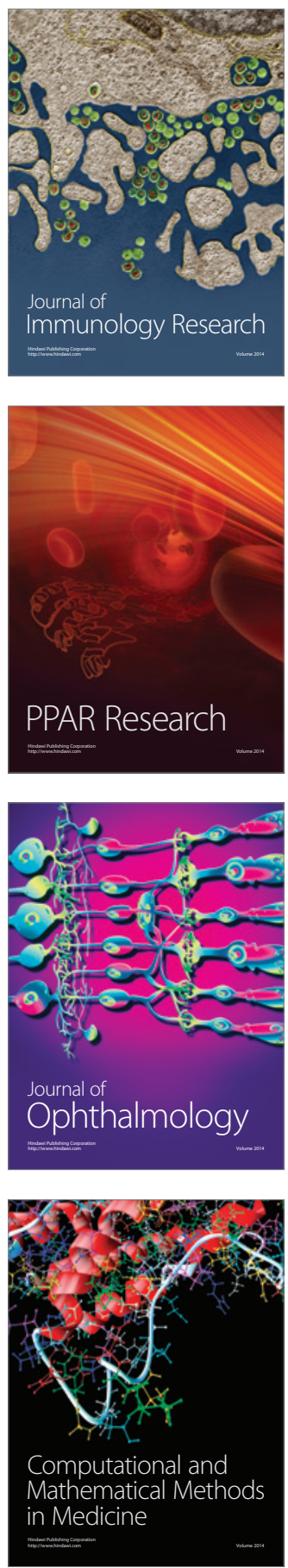

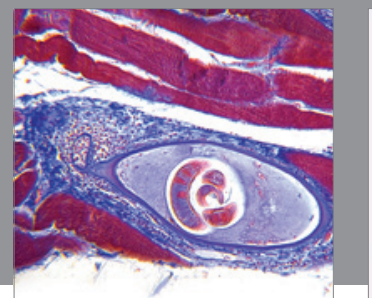

Gastroenterology

Research and Practice
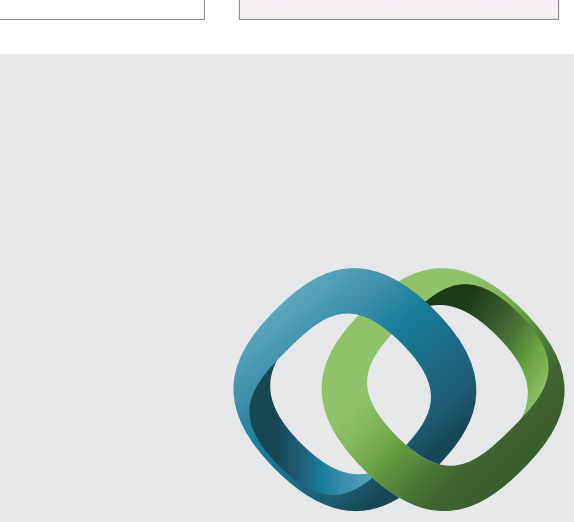

\section{Hindawi}

Submit your manuscripts at

http://www.hindawi.com
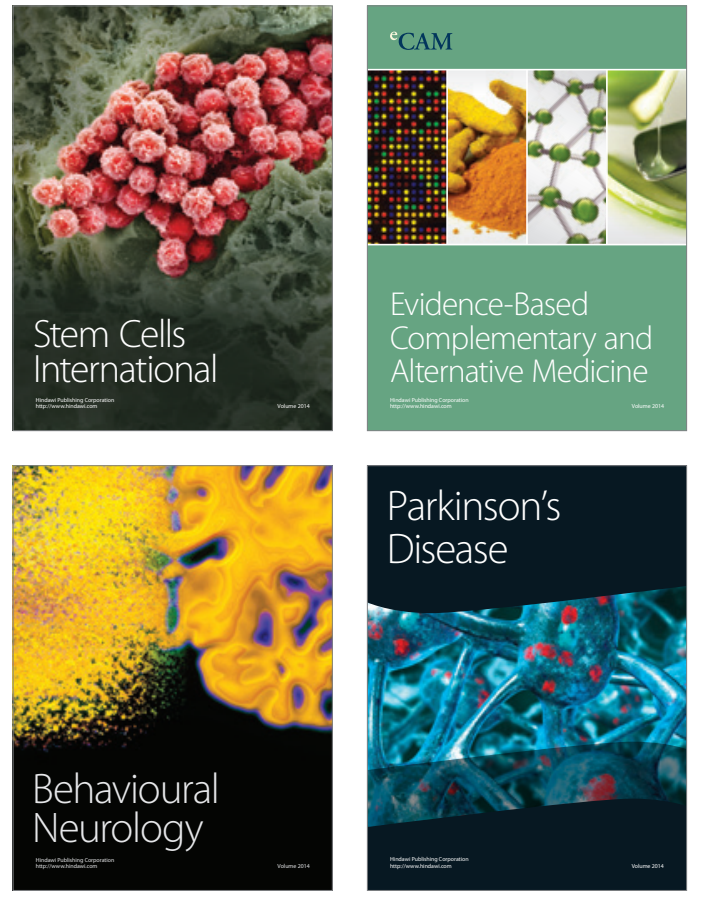
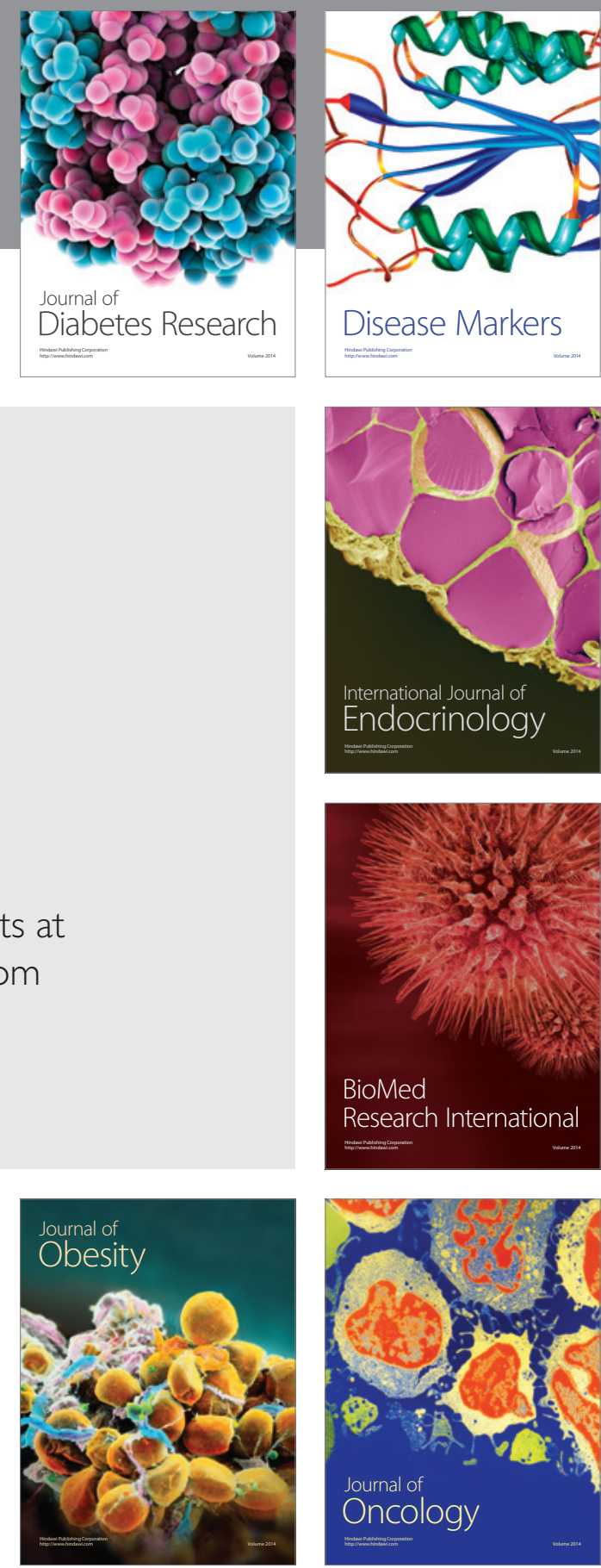

Disease Markers
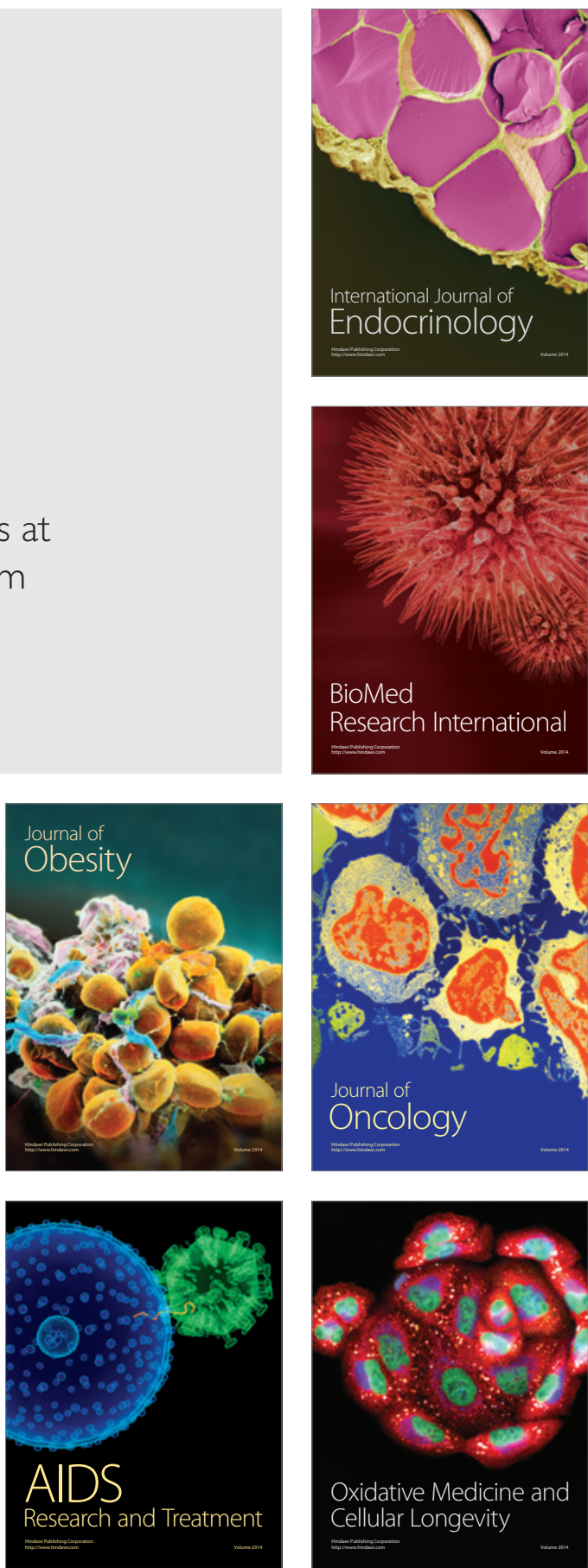